\title{
2008 SRM Rangeland Job Fair
}

\section{The 61st Annual SRM Meeting and Trade Show in Louisville, Kentucky, will be a joint meeting with the American Forage and Grasslands Council (AFGC), January 26-31, 2008.}

$\int$ ust as rangelands are diverse, so are rangeland careers. Just look at the SRM membership as an example of this diversity! In order to better match job opportunities with job seekers, SRM will expand its employment efforts at the 61st Annual SRM Meeting and Trade Show (2008 Joint SRM/AFGC Meeting) in Louisville, Kentucky. SRM announces the 2008 Rangeland Job Fair scheduled for Sunday, January 27, 10:00 AM-6:00 PM. This is a free service for SRM members and Trade Show participants.

The mission of the 2008 Rangeland Job Fair is to match prospective employers from federal agencies, state and provincial governments, private industry, academia, and conservation organizations with the high-caliber, educated, and enthusiastic prospects from SRM. We are also hoping to recruit potential employers from nontraditional sources such as the military. Attendance at the joint meetings, which will be held at the Galt House Hotel and Suites in Louisville, Kentucky, is expected to be between 1,000 and 1,500 people. We expect that approximately $25 \%$ of attendees will be students and young professionals.

The job fair will involve a full day on Sunday, January 27, 2008. Employers will be provided with space to display employment information, distribute vacancy announcements, and interact with job seekers. Registered participants will be provided with one 6-foot table for displays in a large exposition area. For an extra charge, we will also provide $4 \times 8$-foot display boards (see registration form). We will encourage all interested meeting attendees to drift through and browse the job fair between other scheduled activities, meetings, and workshops. Students and young professionals will have two 2-hour blocks of time (10 AM-noon and 4 PM6 PM) completely devoted to the job fair. During these times, we would expect all participants to staff their tables/displays and be prepared to answer questions.

Members of the SRM Young Professionals Conclave (YPC) will be assisting with outreach efforts to employers and employees. If you are interested in this program, or know of prospective employers who may be, please feel free to contact a YPC member (see http://www.rangelands. org/ypc/ypc_index.shtml) or the job fair coordinator, Linda Coates-Markle, BLM Liaison to SRM (1cmarkle@ rangelands.org and/or 303-986-3309).

To register for the 2008 Rangeland Job Fair, please complete the attached form and return it to the address at the bottom of the form. Registration will be on a first-come, first-served basis, and space is limited. The deadline for receipt of all registrations is December 1, 2007. 


\section{SRM RANGELAND JOB FAIR}

\section{REGISTRATION FORM}

The deadline for receipt of registrations is December 1, 2007.

Registrations will be accepted on a first-come, first-served basis.

Name of group or organization:

Name of contact person:

Email for contact:

Telephone:

Mailing address:

City:__ State/Province:____ Postal Code:___ Country:

I plan to participate in the 2008 SRM RANGELAND JOB FAIR. I understand that the JOB FAIR will take place on Sunday, January 27, from 10:00 AM to 6:00 PM. I will set up my display in the designated room between 8:00 AM and 10:00 AM and will remove these materials by 8:00 PM. Basic services (table space) are free for SRM members and registered Trade Show participants. Participants may rent a display board for an extra cost (see below).

Signature

Print Name

Date

TABLE RENTAL COST... FREE to SRM members and Trade Show participants only

$\square$ SRM membership information at http://www.rangelands.org/membership.shtml

$\square$ Trade Show information at http://www.rangelands.org/louisville2008/louisville2008_index.shtml

DISPLAY BOARD RENTAL... extra service requiring payment

$\square \$ 100.00$ for $4 \times 8$ foot display board

CONTRIBUTION TO INTERNET CAFÉ... SRM is planning to set-up an Internet Café for active job seekers at the JOB FAIR. Any and all contributions to support this cause are appreciated... thank you

SPONSORSHIP OF SRM RANGELANDJOB FAIR...Individuals and/or groups interested in sponsoring the JOB FAIR are encouraged to contact the JOB FAIR Coordinator at 303-986-3309.

PAYMENT INFORMATION (check one and complete details as necessary): $\square$ I am enclosing a check made out to SRM. $\square$ I would like to pay by credit card.
Type of card:
$\square$ Visa $\square$ Master Card $\square$ American Express
$\square$ Discover Card

Card \#:

Name on card:

Billing address for card:

Exp mo/yr: Security code (3- or 4-digit on back of card):

To reserve your spot, please FAX this form to (303) 986-3892 or mail to: 2008 SRM RANGELAND JOB FAIR, ATTN: Linda Coates-Markle, 10030 West 27th Avenue, Wheat Ridge, CO 80215-6601.

Questions?? Call SRM at 303-986-3309 or email lcmarkle@rangelands.org 